\title{
Consumers Become More or Less Ethnocentric? A Meta-Analysis on Level of Consumer Ethnocentrism
}

\author{
Gongxing Guo ${ }^{1} \&$ Quan $\operatorname{Lin}^{1}$ \\ ${ }^{1}$ Shantou University Business School, Shantou, China \\ Correspondence: Quan Lin, Shantou University Business School, Shantou, China. E-mail: linquan@stu.edu.cn
}

Received: December 7, 2016

Accepted: January 20, 2017

Online Published: January 26, 2017

doi:10.5539/ijbm.v12n2p145

URL: http://dx.doi.org/10.5539/ijbm.v12n2p145

\begin{abstract}
A huge body of research on consumer ethnocentrism has occurred in cross-cultural consumer behavior research area since the seminal work of Shimp and Sharma (1987). There is, however, a research gap on meta-analysis of the level of consumer ethnocentrism. This study seeks to address this gap by employing, as far as we are aware, the first meta-analysis on level of consumer ethnocentrism. we draw several conclusions with meta-analytical data of 153 mean values in 87 articles during the period of 1987 to $2013(\mathrm{~N}=42840)$ : (1) The average score of consumer ethnocentrism is 3.58 (7 in total); (2) General consumers are more ethnocentric than student consumers; (3) Consumers in developing countries are more ethnocentric than consumers in developed countries.
\end{abstract}

Keywords: consumer ethnocentrism, mean value, cross-cultural consumer behavior, meta-analysis

\section{Introduction}

Image following scenario: If you are going to buy a TV in Wal-Mart, there are many of potential brands that you can choose, such as Sony from Japan, Samsung from South Korea or TCL from China. While you will find there are no essential differences in technological advancement and external design for same type among these brands. How would you make your purchase decision in this case? Ah ha! Of course! You probably buy a TV made in your home country!

With the rapid development of technology in the world today, manufactures are confronted with many challenges such as products homogeneity (Cheng et al., 2013; Gassmann \& Keupp, 2007). Consumers buy something not only depending on the price, quality or design, but also depending on social norm that whether it is appropriateness and morality to buy foreign-made products (Supphellen \& Rittenburg, 2001; Vida \& Reardon, 2008). This belief is well known as consumer ethnocentrism, which is becoming more and more important in consumer purchase decision for transnational consumption (Cleveland et al., 2009; Shimp \& Sharma, 1987).

Since the seminal work of Shimp and Sharma (1987) on concept definition and measurement scale development of consumer ethnocentrism, a growing body of research on this theme has fostered in cross-cultural consumer behavior research area (see a review of Shankarmahesh, 2006). There is, however, a research gap on meta-analysis of the level of consumer ethnocentrism. Consumers become more or less ethnocentric? Which country has the high level ethnocentric consumers and which country is relatively low? How about the differences for level of ethnocentrism between consumers in developing countries and consumers in developed countries? Are there any differences for level of ethnocentrism among general consumers and student consumers? All of which still demand an explicit answer.

This study seeks to address these gaps by employing, as far as we are aware, the first meta-analysis on level of consumer ethnocentrism. The first contribution of this study is achieving the mean value of consumer ethnocentrism from 87 articles during the period of 1987 to 2013. Second, this study compares the level of consumer ethnocentrism horizontally among five most popular countries and shows the longitudinally trend of these five countries. Last but not the least, this study investigates the differences of mean consumer ethnocentrism in different respondents and countries with different economic development levels.

\section{Literature Review and Hypotheses}

When facing with purchase choices between domestic and foreign products, consumer ethnocentrism represents consumers' tendency that whether it is appropriateness to buy foreign-made rather than home country made 
products (Balabanis et al., 2001; Deb \& Roy Chaudhuri, 2012; Sharma, 2011; Shimp \& Sharma, 1987). This tendency is derived from consumers' feelings of ethnocentric insecurity (Siamagka \& Balabanis, 2015); they think buying foreign products may trigger unemployment and other social problems in their home country (Shimp \& Sharma, 1987). With such ethnocentric insecurity perception, they view other countries based on their ethnic group interests and, therefore, hold distorted cognition towards products from these countries (Sharma, 2014; Siamagka \& Balabanis, 2015). As a result, they prefer products made in their home country to other countries, even regardless of the quality and price (Klein, 2002; Shoham \& Brenčič, 2003). In other words, consumer ethnocentrism represents an overall favorable attitude towards domestic products instead of foreign products, which consisting of an affinity for domestic products in affective aspect, an evaluation bias in favor of domestic products in cognitive aspect and, as a result, a preference for domestic rather than foreign products in behavioral aspect (Sharma, 2014; Shimp \& Sharma, 1987; Siamagka \& Balabanis, 2015).

As a form of prosocial behavior (Siamagka \& Balabanis, 2015), consumer ethnocentrism can be learned from an early age and thus, become a kind of enduring general traits (Sharma et al., 1995; Shimp \& Sharma, 1987; Siamagka \& Balabanis, 2015). While the level of consumer ethnocentrism is not always stable but may change over time (Good \& Huddleston, 1995). When consumers at a relatively young age, especially for these young students who are receiving education, they are intensively curious about the world outside and thus, they are less likely to devote themselves to definite ways of life and certain domestic products (Cleveland et al., 2009). As they are getting older, they are aware the adverse consequences that may be caused by import products (Javalgi et al., 2005). The best way to avoid these unfavorable things occurring is buying local and domestic products rather than foreign products (Huddleston et al., 2001; Javalgi et al., 2005). Therefore, compared to younger student consumers, older general consumers are more likely to buy products made in their home country and, certainly, are hold higher level of ethnocentrism (Huang et al., 2010; Javalgi et al., 2005). In light of these arguments, we propose the following:

\section{$\mathrm{H}_{1}$ : General consumers are more ethnocentric than student consumers.}

In addition to time's effect on ethnocentrism, surrounding conditions of consumers will also have an effect on their ethnocentrism (Shankarmahesh, 2006). Consumers will show different ethnocentrism level with changes of surrounding economic conditions of their home country (Siamagka \& Balabanis, 2015). For consumers in less developed countries, their feelings of ethnocentric insecurity probably higher than consumers in developed countries (Kucukemiroglu, 1999; Sharma et al., 1995). They may hold the belief that these developed countries are doing business unfair with their home country (Klein et al., 1998). Such insecurity perception can prompt consumers to take some actions so that other countries cannot get rich of them. Thus consumers in a developing country are more likely to be influenced by some patriotic events such as "buy local" promotional campaigns (Hamin \& Elliott, 2006), as a result, they may hold high level of ethnocentrism (Bandyopadhyay et al., 2011). In light of these arguments, we propose the following:

\section{$\mathrm{H}_{2}$ : Consumers in developing countries are more ethnocentric than consumers in developed countries.}

\section{Method}

We choose articles according to following criteria: (1) the articles must be published in English journals, (2) the research must be quantitative study, (3) mean value of consumer ethnocentrism has been reported, (4) sample size has been reported in corresponding study, (5) each study has exclusive respondent sample.

By searching of databases EMERALD, ELSEVIER, ABI/INFORM and searching on "Web of science" "Google scholar", we finally achieve 153 mean values (effect size) in 87 articles (Note 1) during the period of 1987 to $2013(\mathrm{~N}=42840)$. Specifically, respondents among these studies are mainly from US (17 studies), China (13 studies), India (13 studies), South Korea (11 studies) and Russia (8 studies).

The instrument for measuring consumer ethnocentrism is the CETSCALE that contains multi items with Likert-type statements (Shimp \& Sharma, 1987). To make the mean value of consumer ethnocentrism in different studies comparable, we conduct mathematic conversion as follows:

(a) If the reported value is an average score with a seven-point Likert scale, we select it directly;

(b) If the reported value is an average score with a five-point Likert scale (Note 2), we transfer it by following formula:

The mean value we need $=($ the reported average score $) *(7 / 5)$.

(c) If the reported value is a total score with a seven-point Likert scale, we transfer it by following formula:

The mean vale we need $=($ the reported total score $) /$ (the number of items). 
(d) If the reported value is total score with a five-point Likert scale, we transfer it first by above approach ' $c$ ', and then follow approach ' $b$ '.

\section{Results}

\subsection{The Level of Consumer Ethnocentrism for All Countries}

The average score of consumer ethnocentrism is 3.58 with seven-point Likert-type scale based on 153 effect size in 87 articles during the period of 1987 to 2013, showing moderate level of consumer ethnocentrism for all countries (see Figure 1).

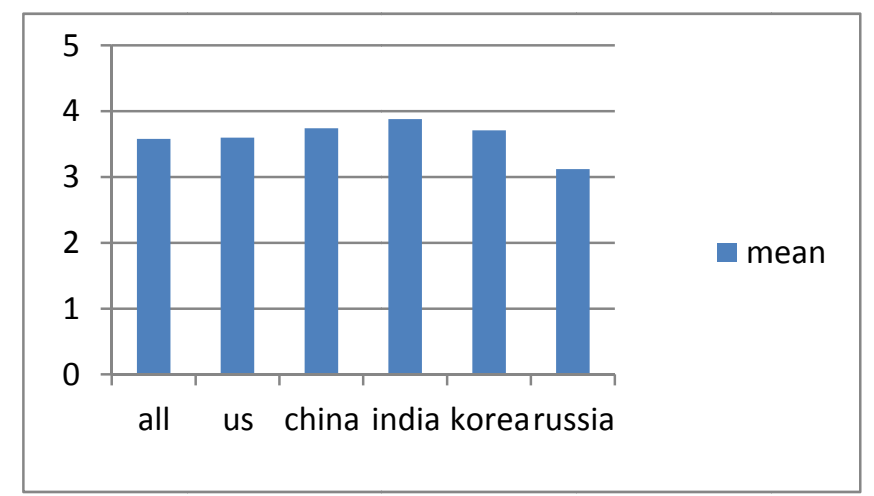

Figure 1. Level of consumer ethnocentrism for all and five main countries

\subsection{The Level of Consumer Ethnocentrism in Main Countries}

Among the five most popular respondents' countries, we compared the level of consumer ethnocentrism. We extracted all mean values of the five countries. The results of the level of consumer ethnocentrism for these five countries as follows: US (3.60), China (3.74), India (3.88), South Korea (3.71), and Russia (3.12). Apparently, Indian consumers hold the highest level of ethnocentrism, followed by Chinese consumers, South Korean consumers and American consumers. Russian consumers hold the lowest level of ethnocentrism, which is the only one less than overall average level among these five countries. Furthermore, the results of T-test show that there is significant difference between India and Russia $(3.88>3.12, t(19)=2.85, p<0.01)$ and marginal significant difference between China and Russia $(3.74>3.12, t(19)=1.78, p<0.10)$.

\subsection{The Trend of Consumer Ethnocentrism in Main Countries}

We then investigated the trend of consumer ethnocentrism in these five counties. Multi-values of each country in the same year were averaged to form a new mean of corresponding year for each country. We achieved thirteen new mean values of US, ten of China, 9 of South Korea, 6 of India and 5 of Russia respectively. The Figure 2 shows the fluctuation for levels of ethnocentrism among the five countries. The level of ethnocentrism for American consumers has experienced a slight increase from 1987 to 2013. The similar tendency can be observed in India. The trend of ethnocentrism for Chinese consumers likes an inverted "V", the peaks can be found during 2006-2009 when the Olympic game were taking place at Beijing, which increased the level of ethnocentrism of Chinese consumers. The trend of ethnocentrism for South Korean consumers shows large fluctuation in the first half, and then keeps stable. Note in particular Russian consumers keep steady trend of ethnocentrism at a relative low level.

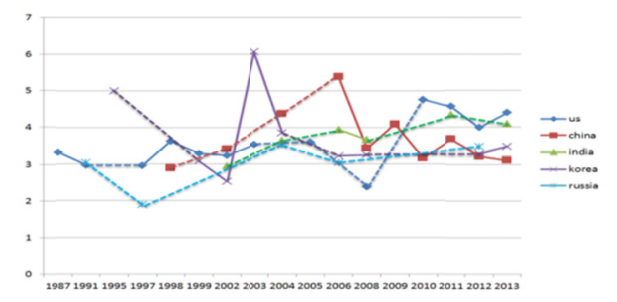

Figure 2. Trend of consumer ethnocentrism in five countries 


\subsection{Hypotheses Testing}

\section{Variables}

\section{Control variables}

Published time: a year names a number. Due to only two articles were published before 1995, one was in 1987 and another was in 1991, these two name 1. From 1995 to 2013, we give the number 2 to 20 for each year successively.

Journal influence: we use the Article Influence scores in http://www.eigenfactor.org, which is a widely recognized journal evaluation method.

\section{Independent variables:}

Sample type: we name general respondents and student respondents as 0 and 1 respectively.

Development level of consumers' home country: we name developed markets as 1, developing markets as 2 .

Dependent variable:

Consumer ethnocentrism: the mean value.

We use SPSS 21 to test our hypotheses. The results can be found in table 1 .

Table 1. Regression results

\begin{tabular}{|c|c|c|c|}
\hline & Model 1 & Model 2 & Model 3 \\
\hline \multicolumn{4}{|l|}{ Control variables } \\
\hline 1. Published time & 0.11 & 0.06 & 0.07 \\
\hline 2. Journal influence & -0.06 & -0.09 & -0.03 \\
\hline \multicolumn{4}{|l|}{ Independent variables } \\
\hline 1. Sample type & & $-0.16 \dagger$ & \\
\hline 2. Development level & & & $0.22 * *$ \\
\hline $\mathrm{R}^{2}$ & 0.02 & 0.04 & 0.06 \\
\hline$\Delta \mathrm{R}^{2}$ & 0.02 & 0.02 & 0.05 \\
\hline $\mathrm{F}$ & 1.14 & 1.93 & $3.18^{*}$ \\
\hline$\Delta \mathbf{F}$ & 1.14 & $3.49 \dagger$ & $7.16^{* *}$ \\
\hline
\end{tabular}

The results show that sample type is negatively related with consumer ethnocentrism $\left(\mathrm{M}_{2}, \beta=-0.16, p<0.10\right)$. It indicates that compared to sample of young students, general consumers are more ethnocentrism. Thus, hypothesis 1 is supported. Furthermore, result of T-test shows the mean of consumer ethnocentrism for general respondents is significantly larger than mean for student respondents $\left(\mathrm{M}_{\text {general }}=3.69, \mathrm{SD}=0.85 ; \mathrm{M}_{\text {student }}=3.38\right.$, $\mathrm{SD}=1.02 ; t(151)=1.97, p<0.05)$, further supporting hypothesis 1 .

Moreover, development level is positively related with consumer ethnocentrism $\left(\mathrm{M}_{3}, \beta=0.22, p<0.01\right)$. It means consumers in developing market are more ethnocentrism than those in developed market. Thus, hypothesis 2 is supported. Furthermore, result of T-test shows the mean of consumer ethnocentrism of developing market is significantly larger than mean of developed market $\left(\mathrm{M}_{\text {developing }}=3.78, \mathrm{SD}=0.88 ; \mathrm{M}_{\text {developed }}\right.$ $=3.35, \mathrm{SD}=0.92 ; t(151)=-2.96, p<0.01)$, further supporting hypothesis 2 .

\section{Conclusion}

The research note of meta-analysis on level of consumer ethnocentrism can be mainly concluded that:

(1) Mean of consumer ethnocentrism is 3.58 with 7-point Likert-type scale based on 153 effect size in 87 articles during the period of 1987 to 2013;

(2) General consumers are more ethnocentric than student consumers.

(3) Consumers in developing countries are more ethnocentric than consumers in developed countries.

(4) Among five popular countries, Indian consumers hold the highest level of ethnocentrism (3.88), followed by Chinese consumers (3.74), South Korean consumers (3.71) and American consumers (3.60). Russian consumers hold the lowest level of ethnocentrism (3.12).

(5) During the period of 1987 to 2013, the levels of ethnocentrism for American and India consumers have 
experienced slight increase, while the trend of ethnocentrism likes an inverted "V" for Chinese consumers, and shows large fluctuation in the first half and then keeps stable for South Korean consumers. Russian consumers, however, keep steady trend of ethnocentrism at a relative low level.

\section{Limitations and Future Research}

There are few limitations in this research.

(1) Although the samples are different in studies that we selected for meta-analyzing, some general consumer samples may contain students due to the situation that general consumers and student consumers in extant research are not strictly mutual independent. Future research should pay more attention to distinguish the two samples and to uncover the different effect of age diversity on consumer ethnocentrism.

(2) This research focus on articles that published from 1987 to 2013, during the period of collecting data, we had tried our best to collected relevant studies. Some studies, however, may still be ignored and are not included in this meta-analytical note. Future research can include and examine those unheeded studies on consumer ethnocentrism.

(3) In this article, we mainly focused on the level of consumer ethnocentrism among different countries. There are more issues of consumer ethnocentrism need to further explore. For example, a comprehensive meta-analysis on relationships of consumer ethnocentrism and its antecedents and consequences is a meaningful future research avenue.

\section{Acknowledgements}

This article was supported by the Humanities and Social Sciences Foundation of the Ministry of Education in China (13YJA630049), the Natural Science Foundation of Guangdong in China (2015A030313450), the Guangdong Planning Program of Philosophy and Social Science in China (GD16YGL05), STU Scientific Research Initiation Grant (STF16007) and STU Cultivated Program for National Funds (NFC16006).

\section{References}

Balabanis, G., Diamantopoulos, A., Mueller, R. D., \& Melewar, T. C. (2001). The impact of nationalism, patriotism and internationalism on consumer ethnocentric tendencies. Journal of International Business Studies, 32(1), 157-175. http://dx.doi.org/10.1057/palgrave.jibs.8490943

Bandyopadhyay, S., Wongtada, N., \& Rice, G. (2011). Measuring the impact of inter-attitudinal conflict on consumer evaluations of foreign products. Journal of Consumer Marketing, 28(3), 211-224. http://dx.doi.org/10.1108/07363761111127635

Cheng, P., Man, P., \& Yi, C. H. (2013). The impact of product market competition on earnings quality. Accounting \& Finance, 53(1), 137-162. http://dx.doi.org/10.1111/j.1467-629x.2011.00457.x

Cleveland, M., Laroche, M., \& Papadopoulos, N. (2009). Cosmopolitanism, consumer ethnocentrism, and materialism: An eight-country study of antecedents and outcomes. Journal of International Marketing, 17(1), pp. 116-146. http://dx.doi.org/10.1509/jimk.17.1.116

De Ruyter, K., Van Birgelen, M., \& Wetzels, M. (1998). Consumer ethnocentrism in international services marketing. International Business Review, 7(2), 185-202. http://dx.doi.org/10.1016/s0969-5931(98)00005-5

Deb, M., \& Roy Chaudhuri, H. (2012). Assessing the ethnocentric tendencies of different age-cohorts in an emerging market. Journal of Indian Business Research, 4(4), 244-268. http://dx.doi.org/10.1108/17554191211274776

Gassmann, O., \& Keupp, M. M. (2007). The competitive advantage of early and rapidly internationalising SMEs in the biotechnology industry: A knowledge-based view. Journal of World Business, 42(3), 350-366. http://dx.doi.org/10.1016/j.jwb.2007.04.006

Good, L. K., \& Huddleston, P. (1995). Ethnocentrism of Polish and Russian consumers: Are feelings and intentions related. International Marketing Review, 12(5), 35-48. http://dx.doi.org/10.1108/02651339510103047

Hamin, \& Elliott, G. (2006). A less-developed country perspective of consumer ethnocentrism and "country of origin" effects: Indonesian evidence. Asia Pacific Journal of Marketing and Logistics, 18(2), 79-92. http://dx.doi.org/10.1108/13555850610658246

Huang, Y. A., Phau, I., \& Lin, C. (2010). Effects of animosity and allocentrism on consumer ethnocentrism: Social identity on consumer willingness to purchase. Asia Pacific Management Review, 15(3), 359-376. 
http://dx.doi.org/10.6126/APMR.2010.15.3.04

Huddleston, P., Good, L. K., \& Stoel, L. (2001). Consumer ethnocentrism, product necessity and Polish consumers' perceptions of quality. International Journal of Retail \& Distribution Management, 29(5), 236-246. http://dx.doi.org/10.1108/09590550110390896

Javalgi, R. G., Khare, V. P., Gross, A. C., \& Scherer, R. F. (2005). An application of the consumer ethnocentrism model to French consumers. International Business Review, 14(3), 325-344. http://dx.doi.org/10.1016/j.ibusrev.2004.12.006

Klein, J. G. (2002). Us versus them, or us versus everyone? Delineating consumer aversion to foreign goods. Journal of International Business Studies, 33(2), 345-363. http://dx.doi.org/10.1057/palgrave.jibs. 8491020

Klein, J. G., Ettenson, R., \& Morris, M. D. (1998). The animosity model of foreign product purchase: An empirical test in the People's Republic of China. Journal of Marketing, 62(1), 89-100. http://dx.doi.org/10.2307/1251805

Kucukemiroglu, O. (1999). Market segmentation by using consumer lifestyle dimensions and ethnocentrism: An $\begin{array}{llll}\text { empirical study. European Journal of Marketing, 33(5/6), 470-487. } & \text {. }\end{array}$ http://dx.doi.org/10.1108/03090569910262053

Shankarmahesh, M. N. (2006). Consumer ethnocentrism: An integrative review of its antecedents and consequences. International Marketing Review, 23(2), 146-172. http://dx.doi.org/10.1108/02651330610660065

Sharma, P. (2011). Country of origin effects in developed and emerging markets: Exploring the contrasting roles of materialism and value consciousness. Journal of International Business Studies, 42(2), 285-306. http://dx.doi.org/10.1057/jibs.2010.16

Sharma P. (2014). Consumer ethnocentrism: Reconceptualization and cross-cultural validation. Journal of International Business Studies, 46(3), 381-389. http://dx.doi.org/10.1057/jibs.2014.42

Sharma, S., Shimp, T. A., and Shin, J. (1995). Consumer ethnocentrism: A test of antecedents and moderators. Journal of the Academy of Marketing Science, 23(1), pp. 26-37. http://dx.doi.org/10.1007/bf02894609

Shimp, T. A., \& Sharma, S. (1987). Consumer ethnocentrism: Construction and validation of the CETSCALE. Journal of Marketing Research, 24(3), 280-289. http://dx.doi.org/10.2307/3151638

Siamagka, N. T., \& Balabanis, G. (2015). Revisiting consumer ethnocentrism: Review, reconceptualization, and empirical testing. Journal of International Marketing, 23(3), 66-86. http://dx.doi.org/10.1509/jim.14.0085

Shoham, A., \& Brenčič, M. M. (2003). Consumer ethnocentrism, attitudes, and purchase behavior: An Israeli study. Journal of International Consumer Marketing, 15(4), 67-86. http://dx.doi.org/10.1300/j046v15n04_04

Supphellen, M., \& Rittenburg, T. L. (2001). Consumer ethnocentrism when foreign products are better. Psychology \& Marketing, 18(9), 907-927. http://dx.doi.org/10.1002/mar.1035

Vida, I., \& Reardon, J. (2008). Domestic consumption: Rational, affective or normative choice? Journal of Consumer Marketing, 25(1), 34-44. http://dx.doi.org/10.1108/07363760810845390

\section{Notes}

Note 1. The full references list of articles are available under requiring.

Note 2. An exceptional goes to the research of De Ruyter et al (1998), which used a nine-point Likert scale. We replace 5 with 9 in the formula to achieve the mean value that can be comparable.

\section{Copyrights}

Copyright for this article is retained by the author(s), with first publication rights granted to the journal.

This is an open-access article distributed under the terms and conditions of the Creative Commons Attribution license (http://creativecommons.org/licenses/by/4.0/). 